\title{
Women on the two-year transfer pathway in engineering
}

\section{Dr. Emily Knaphus-Soran, University of Washington}

Emily Knaphus-Soran is a Senior Research Scientist at the Center for Evaluation \& Research for STEM Equity (CERSE) at the University of Washington. She works on the evaluation of several projects aimed at improving diversity, equity, and inclusion in STEM fields. She also conducts research on the socialpsychological and institutional forces that contribute to the persistence of race and class inequalities in the United States. Emily earned a PhD and MA in Sociology from the University of Washington, and a BA in Sociology from Smith College.

\section{Dr. Roberta Rincon, Society of Women Engineers}

Dr. Roberta Rincon is the Senior Manager of Research with the Society of Women Engineers, where she oversees the organization's research activities around issues impacting girls and women from elementary through college and into the engineering workforce. Before joining SWE, Roberta was a Senior Research and Policy Analyst at The University of Texas System, where she focused on student success and faculty teaching and research award programs across nine academic institutions. Roberta received her B.S. in Civil Engineering from The University of Texas at Austin, an MBA and an M.S. in Information Management from Arizona State University, and a Ph.D. in Educational Policy and Planning from UT Austin.

\section{Alexandra Schaefer, University of Washington}




\section{Women on the two-year transfer pathway in engineering}

\section{Introduction}

Community colleges provide a pathway for many students interested in pursuing higher education, but who seek a more flexible and less expensive alternative to a traditional four-year university program. Among the millions of undergraduates in the U.S., 25\% are older than 25 years of age, and approximately $40 \%$ work at least 30 hours per week [2]. Over $40 \%$ of undergraduates in the U.S. attended a public two-year college in 2017-18 [1]. Between 2010 and 2017, almost half of U.S. baccalaureate degree earners had done some coursework at a community college, and almost $20 \%$ had earned an associate's degree [3].

The National Academy of Engineering (NAE) has highlighted the importance of community colleges in broadening participation in engineering because of the diversity they represent [4], [5]. In fall 2017, approximately $43 \%$ of Hispanic undergraduates, $42 \%$ of American Indian/Alaskan Native undergraduates, and $35 \%$ of Black undergraduates were enrolled in two-year institutions across the United States [1]. Among women, 31\% of undergraduate students were enrolled in twoyear colleges in fall 2017 [1]. More attention to supporting students on the transfer pathway into engineering could yield greater diversity in the profession, given that over $80 \%$ of first-time community college students indicate that they want to complete their bachelor's degree or higher [6]. The National Student Clearinghouse [7] has also found that over $60 \%$ of associate degree earners go on to enroll in a four-year institution within the next six years, and this percentage is higher for those who were 20 years old or younger when they earned their associate degree.

Given that (1) approximately $15 \%$ of two-year college students declare a major in engineering or computer science, (2) over $65 \%$ of students who declare an engineering major and transfer to a four-year university eventually complete an engineering baccalaureate degree, and (3) many underrepresented groups (including women and minorities) begin their education at a community college, the transfer pathway to an engineering or computer science (ECS) degree shows great promise in helping us increase diversity in these fields [8], [9].

The challenge we face is that only $33 \%$ of community college students, regardless of major, successfully transfer [10]. In addition to low transfer rates, a 2017 study by the Society of Women Engineers found that women who begin their engineering and computer science studies at a twoyear institution have higher rates of switching out of these majors than their male counterparts [11]. One faculty member from our current study had observed this phenomenon directly:

In my classroom, when it is an introductory course... [the gender split is] almost half and half, 50-50, and sometimes the female students are actually dominant compared to the male students at the introductory level courses. When we get to the advanced courses in computer science, we are lucky if we have two or three female students.

The current study was undertaken to understand why women on the community college transfer pathway are choosing to leave ECS and what can be done to increase women's persistence. 


\section{Methods}

Our mixed-methods approach allows for a quantitative exploration of differences in the community college engineering experience based on gender identity. Our qualitative approach provides a deeper look into dimensions of this experience for women on the transfer pathway and their perception of factors contributing to success.

\section{Quantitative methods}

Survey data were collected from 414 students aged 18 or older at three community colleges in Texas between April and September 2019. Select demographics of the sample are shown in Table 1, more detailed demographic information can be found in Appendix B. The survey captured information on students' self-efficacy, inclusion, motivation, and confidence in ECS using previously-validated measures from the Longitudinal Assessment of Engineering Self-Efficacy (LAESE) [12] and the Academic Pathways of People Learning Engineering (APPLES2) [13]. Scores for each multi-item measure were calculated and normalized to a $0-100$ scale, and the means of these measures were compared across gender and race/ethnicity groups using independent samples t-tests. The survey items which contribute to each scale are reported in Appendix A. Respondents also provided information on their educational history, current area of study, and intentions to pursue a baccalaureate degree and career in ECS. Intentions to pursue a baccalaureate degree and career in ECS were compared between gender and race/ethnicity groups

Table 1: Demographic characteristics of survey respondents

\begin{tabular}{|lll|}
\hline & Frequency & Percent \\
\hline Institution: & & \\
\hline School A & 225 & 54.3 \\
School B & 24 & 5.8 \\
School C & 165 & 39.9 \\
Total & 414 & 100.0 \\
\hline Gender: & & \\
\hline Woman & 106 & 32.8 \\
Man & 210 & 65.0 \\
Genderqueer/nonbinary & 1 & .3 \\
Prefer not to answer & 6 & 1.9 \\
Total & 323 & 100.0 \\
\hline URM ${ }^{2}$ status: & & \\
\hline Non-URM & 160 & 49.1 \\
URM & 157 & 48.2 \\
Prefer not to answer & 9 & 2.8 \\
Total & 326 & 100.0 \\
\hline
\end{tabular}
using chi-squared tests. Logistic regression was utilized to examine the relationships between intentions to pursue ECS and demographic characteristics, motivation, inclusion, and efficacy measures.

\section{Qualitative methods}

The research team conducted eight qualitative interviews with students recruited from the pool of survey respondents. Students were contacted if they indicated a willingness to participate in an interview, identified as a woman ${ }^{1}$, and expressed an intention to pursue a bachelor's degree in engineering. In order to develop an understanding of factors contributing to success for students most marginalized in engineering, recruitment efforts were primarily targeted towards students

\footnotetext{
${ }^{1}$ The one respondent identifying as genderqueer/nonbinary was not recruited because they did not provide an email address for interview follow-up
} 
from racial/ethnic groups minoritized in STEM (URM²: American Indian or Alaska Native; Black, African, or African American; Hispanic, Latino/a/x, or Chicano/a/x; or Native Hawaiian or Pacific Islander). Four community college engineering faculty members were also interviewed for this study. Their observations of the institutional supports and barriers were useful in helping the researchers understand the experiences of students on this pathway. Interviews were transcribed and coded using Dedoose software. A coding scheme was developed inductively based on commonly occurring themes and themes relevant to existing literature. The aim of this study was to identify factors contributing to persistence of women in engineering, so particular attention was paid to respondents' reflections on both supports received and barriers faced in their pursuit of engineering at a community college. Detailed demographic characteristics of interview respondents are reported in Appendix B.

\section{Findings}

\section{Motivation to study engineering and choice of major}

Research indicates that about $70 \%$ of students who complete bachelor's degrees in engineering intended to do so as early as their senior year in high school and motivations for studying engineering remain relatively stable throughout college; so understanding what motivates students to pursue an engineering career is important for developing strategies to engage students early in their community college pathway [16], [17].

Our study suggests that men and women have similar motivations for studying engineering. Survey respondents indicated that they were most motivated by intrinsic behavioral and psychological factors, such as a desire to build things. Students also reported a high degree of social good motivation (i.e. a belief that technology and engineering skills contribute to the good of society). Unlike previous research using the same survey instrument with undergraduate students at fouryear universities [16], women in the current study were slightly more inclined to express social good motivation than men, and this difference was statistically significant $(\mathrm{p}<.05)$. Both survey respondents and interview participants were less strongly motivated by parents or mentors, and by financial factors such as the belief that engineers are well-paid. Items used to construct motivation scales are presented in Appendix C.

Our study found gendered differences in survey respondents' choice of major within engineering. Women were more likely than men to be interested in pursuing civil engineering, biomedical engineering, and to be undecided about their major. Men were more likely to be interested in pursuing mechanical engineering and electrical engineering. Differences in gender diversity across disciplines found in this study are similar to other studies that have shown that men are most overrepresented in mechanical engineering, electrical engineering, and computer engineering, while bioengineering, civil engineering, industrial engineering, and chemical engineering attract more women [14], [15].

\footnotetext{
2 For the purposes of this report, we use the term "underrepresented minority" (URM) as a shorthand to describe racial/ethnic groups minoritized in STEM while acknowledging that the term overlooks the social/historical processes that result in the underrepresentation of some groups.
} 


\section{Confidence and self-efficacy}

Survey data showed no statistically significant association between demographic characteristics (gender or racial/ethnic identity) and engineering self-efficacy. However, there were some associations between demographic characteristics and confidence in skills related to careers in engineering. Students who were older tended to be more confident in professional and interpersonal skills. Age was also associated with greater confidence in solving open-ended problems, as was lower income. Confidence in professional and interpersonal skills did not vary by gender according to our survey, but interviews revealed that some women students are concerned with others' perceptions of their leadership capability. Consistent with other research, our survey findings show that men are more confident in math and science skills than women, but these differences are small (see Figure 1). While the relationship between confidence and intention to persist in STEM was not statistically significant in our findings, recent studies show that cultural stereotypes of men's superiority in math is related to increased confidence for men in math and the "overpersistence" of men in STEM [18]. For women, confidence rather than ability in math contributes to higher rates of attrition from STEM - women are less confident, even when performance is equal or superior to men's [19].

Confidence and Self-Efficacy by Gender

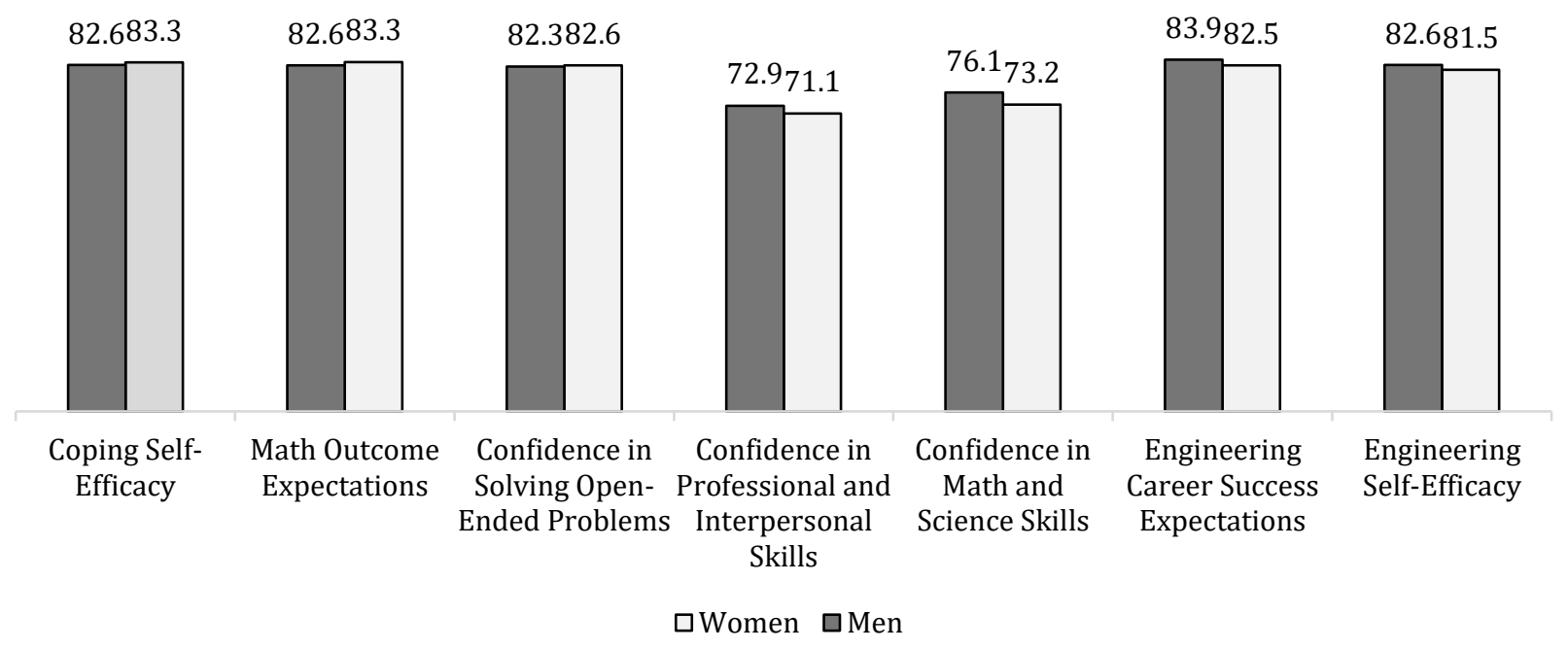

Figure 1: Confidence and self-efficacy by gender

\section{Inclusion}

Contrary to previous research on gender inequity within engineering, survey respondents reported a similar sense of inclusion in engineering regardless of their gender or race/ethnicity (agreeing at similar rates to items such as "I can relate to the people around me in my class" and "I have a lot in common with the other students in my classes") ${ }^{3}$. However, interviewees expressed that the lack of women in engineering classes and professions sometimes caused doubts about whether they

\footnotetext{
${ }^{3}$ Sense of inclusion was measured using LAESE multi-item variables as reported in Appendix C.
} 
belong in the field. About half of interviewees mentioned the lack of women in engineering and the need for more women engineers.

Age more than gender, race, or ethnicity, arose as theme that set some interview respondents apart from their peers. Generally, older students reported that their younger peers look to them as a resource. Some respondents expressed that due to the pressures of busy schedules, they do not interact much with their peers socially. Overall, though, there was a sense that the drive to complete engineering degrees was a quality shared by interviewees and their peers.

\section{Involvement in engineering professional organizations}

Eight percent of women and $12 \%$ of men responding to the survey reported that they were involved in a professional engineering organization (such as the American Society of Mechanical Engineers), though a quarter of women were involved with the Society of Women Engineers. A smaller portion of respondents (2-5\%) were involved with the National Society of Black Engineers or the Society of Hispanic Professional Engineers. Whether they were affiliated with a professional engineering organization or not, students interviewed noted a number of useful benefits associated with membership, including that they can be a great source of information, both directly and through other students involved. Students also discussed a desire to connect both with other engineering students and with professionals working in the field. They expressed that more connections with professional engineers could help them better understand their career options. Related to networking, mentorship appears to be an important piece missing from several students' experiences and could be a clear way for professional organizations to influence the next generation of engineers. Interviewees were as interested in connections to job opportunities as they were in information related to engineering in general, and about making connections to other engineers. This benefit of professional organizations was usually discussed in conjunction with learning, professional development, and networking.

Institutional factors impacting the experience of women in engineering

A 2011 study found that certain institutional supports, including faculty inspiration to pursue STEM careers, peer academic support, and helpful transfer advising, can influence women's persistence in STEM [20]. Students interviewed for the current study mentioned a number of institutional supports that helped as they progressed on their CSE trajectory, including partnership programs, college centers, faculty support, and quality advising.

\section{$\underline{\text { Partnership programs }}$}

Though there are few studies that have looked at STEM partnership programs, there is evidence that community college transfer retention is higher for students who have participated in partnership programs that include resources specifically for transfer students and offer coordinated academic advising, peer mentoring, and support for the development of social and professional networks [21]-[23]. In Texas, state-level efforts to improve academic transfer pathways from two- 
year to four-year institutions include the Texas Pathways ${ }^{4}$, a strategy focused on designing and implementing structured academic and career pathways for all community college students. Some students and faculty interviewed spoke of the Texas A\&M University's Engineering Academies, which allow students to take mathematics, science, and core curriculum courses at the community college while also taking engineering courses from Texas A\&M faculty on the community college campus.

\section{$\underline{\text { Community college offices and centers }}$}

Some students mentioned specific centralized resource hubs geared toward students with specific needs or backgrounds that supported their studies by providing a broad range of supports. For example, one student relied on the mathematics, engineering, and science center on her campus for tutoring, computer access, and connecting with a community of peers. Other students relied on the veterans office or international students office to receiving advising and get connected with other resources. Research shows that when students gain positive learning and study skills, including time management and problem solving skills, at a community college, it can have a positive influence on students' academic transfer adjustment [24], [25].

\section{Faculty}

Research has found that helpful professors and advisors after transfer were key to keeping students from switching out of their STEM major [20]. But faculty can have a great impact on students' success prior to transfer as well. Among our survey respondents, women were more likely to report interacting with faculty in class and during office hours, but men were more likely to interact with faculty outside of class and office hours. In terms of satisfaction with instructors, most survey respondents reported being satisfied or very satisfied with both the availability of instructors outside of class time, and with the quality of teaching at their institution. While positive connections with faculty helped to keep students engaged in engineering, some interview respondents had issues with the way they or other students were treated by faculty. For example, one student stated that an instructor told them "this is a piece of cake" in front of the whole class, in response to a question she had asked. Though she was able to brush it off, she felt like actions like that on the part of instructors made some of her peers resistant to ask questions in class out of fear of "looking stupid".

\section{Advising}

Quality academic advising can have a positive impact on student retention and satisfaction [26], [27]. For community college students in STEM, discipline-specific advising can be especially helpful because students can see the roadmap they need to follow to complete their degree [4]. A study by Laanan et al. [24] found that students' academic counseling experiences at a community college can negatively influence the academic adjustment of students after transfer. Inadequate

\footnotetext{
${ }^{4}$ To learn more about the Texas Success Center and the Texas Pathways project, visit https://tacc.org/tsc.
} 
advising, counseling, and tutoring can also factor into students' decisions to switch out of STEM majors [26].

Students interviewed for our study described advising as hit or miss. Some students said that they had made great connections with advisors, particularly advisors within a specific focus such as STEM or international students. The handful of students who said that their college advising had been helpful indicated that they felt like they were receiving the information they needed to successfully transfer to a university. Other students said that they relied more on transfer advisors from their target four-year university rather than advisors at the community college to help them develop their academic plan. One student indicated that she felt she got better help from her friends than from advisors, stating:

They never, they never put themselves in the student's shoes. So the explanation is really uncaring, I guess? It's not like they are, you know, being mean to us or anything. But they don't understand us at all.

One concerning issue that arose was about receiving incorrect information about transfer requirements from an advisor at the community college. An interview respondent shared her experience of being told that her credits won't count, which turned out not to be true, so she stopped going to speak with her advisor. Faculty interviewed noted that transfer advising is a big issue, not just locally, but nationwide. One faculty said that her college has a number of transfer agreements in place, but advising over 3,000 students about them can be a challenge.

Please rate your satisfaction with your institution on...

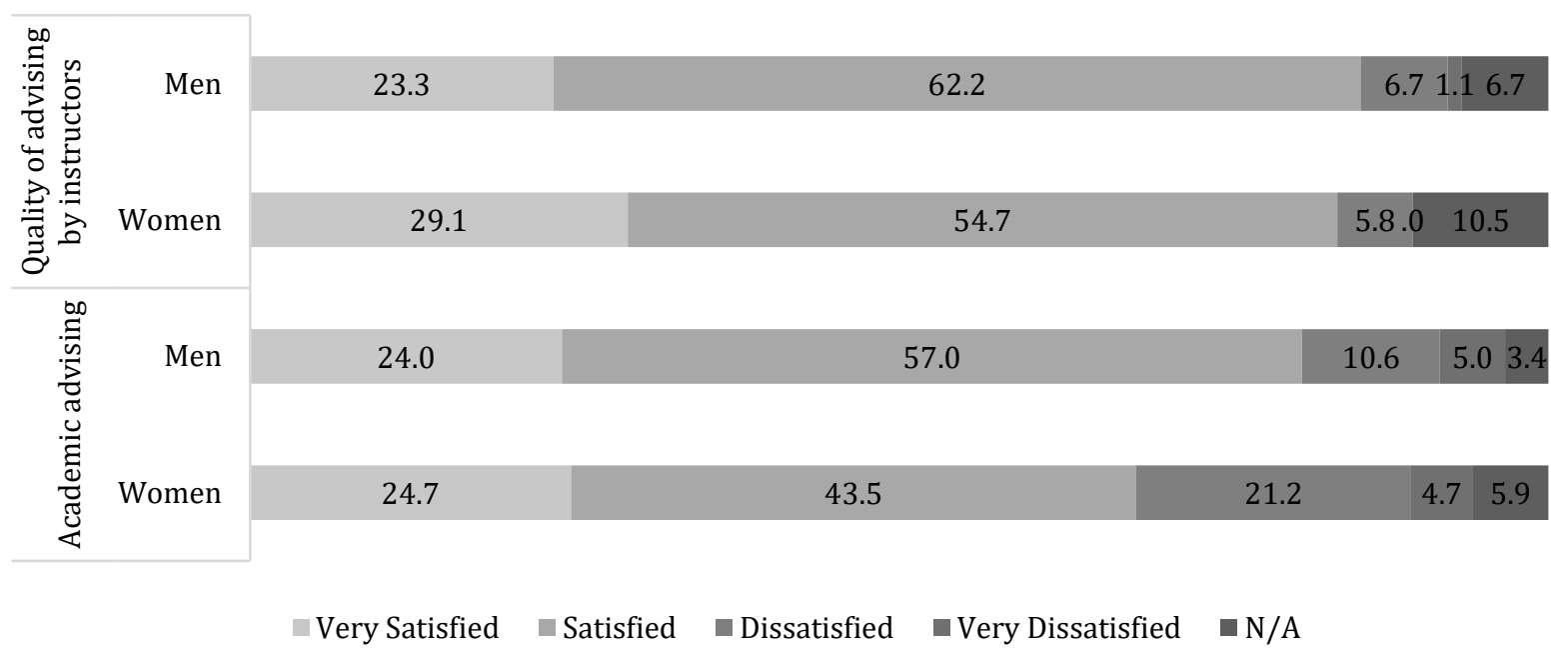

Figure 3: Satisfaction with advising by gender

Survey respondents, reflecting the feelings of the interviewees, were more divided on their satisfaction with academic advising than their satisfaction with other aspects of campus life, such as the quality of teaching, and women reported being less satisfied then men, with about a quarter 
of women respondents saying they were dissatisfied or very dissatisfied with academic advising. In contrast, $15.6 \%$ of men responded that they were dissatisfied or very dissatisfied with academic advising (see Figure 3).

\section{Personal and relational factors contributing to persistence in engineering}

When discussing their success in engineering, students frequently mentioned aspects of their personality, other individual characteristics, and meaningful relationships that helped them to progress on their pathway and overcome challenges.

$\underline{\text { Individual assets }}$

In addition to confidence and belief in innate academic abilities, the primary individual assets that students described as contributing to their success in engineering were perseverance and being proactive. Half of the interview respondents described themselves as persistent and resilient when faced with challenges and unwilling to give up on reaching their goals. Over half also described their ability to be proactive and seek the help they need if (or even before) they're struggling. One respondent said that she tended to do really well in her engineering-related coursework, and she attributed her success to her willingness to ask questions: "I find that a lot of the guys in my classes don't want to look dumb so they never ask questions and then they don't do well in the classes and it's totally baffling to me. I would just say if you feel like you got a question then just ask." When asked about whether she interacts with instructors outside of class, another said "Yes, I am always after them."

\section{$\underline{\text { Support from family, friends, and peers }}$}

Several students discussed ways in which personal connections had influenced their experience in engineering. For many, individual personal connections were key for their success in engineering at the community college, whether this be family and friends providing encouragement, faculty mentors providing opportunities and guidance, or school peers providing academic and social support where faculty support was lacking. This is consistent with research showing that STEM pathways are influenced not only by the educational institution, but also by relationships [28], [29]. Research shows that women of color in particular rely on family and community support to help encourage them to complete their STEM degrees [30].

Students discussed receiving a variety of types of support from their families to pursue their engineering education. For some, support was instrumental or informational, particularly for those who were not the only members of their family in college. Other respondents emphasized the emotional support their family provided. Students also receive both instrumental/informational support and emotional support from friends. Students made connections with other students in engineering, and used these connections to form study groups, receive academic help, and to commiserate/discuss their shared struggles. Other students found social/emotional support by participating in campus organizations. 


\section{$\underline{\text { Mentors }}$}

Over half of our interview respondents described the importance of mentors (even if not identified as such) in encouraging them to pursue engineering or providing them with guidance and opportunities. A 2007 literature review of research on effective strategies to increase diversity in STEM discussed the important role that mentoring plays in the educational progress of underrepresented students, noting that a combination of both faculty and peer mentors is likely the best way to meet the needs of students seeking mentorship [26]. While mentorship is known to be important for success, students interviewed for our study had little knowledge of how or why to find a mentor. When asked whether they had a mentor, only two out of the eight respondents said yes. An additional three respondents discussed similar relationships they had with helpful peers or faculty that could be considered mentors, though they did not use that term to describe them. Two of these respondents explicitly said that these trusted advisors were not mentors.

Among students who didn't describe having a mentorship-like relationship, two said that that they had not received any sort of guidance or information on how to find or approach a mentor. Research on the importance of mentorship and our findings that students have a hard time articulating the how and why of finding a mentor illustrate a need for more focus on mentorship for students on the community college pathway in engineering.

\section{Barriers to completing a bachelor's degree in engineering}

Research on the experience of students on the community college pathway frequently discusses the additional demands on time and finances that these students experience alongside their education. Students interviewed for this study were no different. However, there were other factors mentioned that students felt could also hamper their progress towards a degree.

\section{$\underline{\text { Financial barriers and family commitments }}$}

Students frequently mentioned commitments and challenges outside of school that took attention away from their schoolwork. Finances play an important role in students' decisions to enroll in a two-year institution. Educational costs vary depending on the program a student selects, with courses in engineering and science being more expensive than those in the humanities and social sciences [31]. A 2006 study of STEM students found that those who completed their degrees were from higher income families, and those who did not complete their degrees were more likely to work 15 or more hours per week [32].

Most respondents in this study discussed financial challenges they faced and the necessity of working while in school. For these students, financial strain was the primary reason why they chose to attend community college rather than starting at a four-year university. Many still struggled to pay for community college, even though it was the less expensive alternative. These respondents described the difficulty of balancing work and life demands.

Other students interviewed discussed family commitments that placed a considerable demand on their time. Women typically take on more child care and household responsibilities than men, which can make a successful completion of a STEM degree challenging [33]. Two students in our 
study mentioned the impact that having partners and children has had on their educational trajectory. Both of these mothers discussed starting college later in life because they started families young. One of these mothers talked about how she copes with the demands on her time by keeping a very rigid schedule:

When I get home sometimes, depending on what time I get home, I'll say, "Okay, family, I have 30 minutes," and I set the timer, as in like, "Okay bye," and I go upstairs and go sit down and start studying.

While financial strain can be an obstacle to degree completion, one student explained that this struggle was something shared between she and her peers and contributed to solidarity.

\section{$\underline{\text { Personality factors \& academic preparation }}$}

Some students expressed concerns related to their own individual personality or characteristics that they believe may be hindering their success. For some, it was apprehension about math and science preparation as they prepared to take classes in these subjects at the community college. Some students expressed concern about their level of academic preparation prior to transferring to a university to complete their degree. One student interviewed mentioned that the length of time between when she graduated from high school and when she started college made her lose a lot of her fundamental math skills, so it was a steep learning curve to return to school. Other personality traits mentioned by those in our study that made their academic journey more difficult included indecisiveness, procrastination, and a lack of confidence.

\section{Lack of family support}

While families were generally supportive to students pursuing an engineering degree, one student interviewed said that people in her network had expressed skepticism about her ability to balance school and family. Faculty we spoke with also noted instances of students expressing a lack of support from their families, particularly among first-generation college students. They indicated that some students think college is hard, that engineering is hard, and they believe it stems from not knowing anyone in college:

[First-generation college students] have no idea what real college, or transfer, or transition or anything is going to be, because no one's told them before what it's like to be in college before cause no one in their family's done it. And it goes on further where they're actually talked to negatively about college.

Another faculty member observed gender differences in how students' families sometimes reacted to their decision to major in engineering:

I've had women come in and tell me that, you know, "My parents won't pay for me to study engineering because it's just not an appropriate occupation for a woman. It's okay for my brother, but it's not okay for me." 


\section{What can schools and professional organizations do to support women in engineering?}

\section{Improve advising for transfer students}

Both students and faculty in our study indicated that advising for transfer students needs to be improved. While efforts are being made at local, regional, and state levels to provide more information to students about what courses are needed for their chosen major, as well as what courses will be accepted at their prospective transfer institution, the concerns expressed indicate that a lack of information is not the problem. Rather, there is a need for students to be advised by someone who can help them navigate through the information and help them solidify their transfer plan. Unfortunately, our findings indicate that students often feel uncertain about the help they receive from advisors at their colleges. Given the student-to-advisor ratio that many colleges face, it is not surprising that some students find it difficult to gain quality time with their assigned advisor. Proactive students are able to find the help they need, either through other departments or from their prospective transfer institution. It is those students who are unsure how to navigate the college environment, and who are in most need of guidance, who may be falling through the cracks.

\section{Provide more financial support}

Students shared the financial challenges that they face as they pursue their college education. For some, the cost of attending college was the primary reason for beginning their bachelor's degrees at a community college. Others spoke of the impact that working while taking classes had on their ability to make time for school-related activities, including their ability to enroll full-time.

A study in California found that only about $10 \%$ of transfer students received financial aid while enrolled at a community college [27]. Scholarships and other forms of financial support could help provide students more time to focus on their engineering studies. Paid internships and other forms of employment that expose students to hands-on engineering projects while also providing monetary support as they pursue their education could help encourage students to stay in ECS majors through transfer and graduation.

\section{Provide more information about career pathways}

Women gained less knowledge than men about engineering as a profession while in college. Survey results showed that school-related experiences were the most frequent form of exposure to engineering for students on the community college pathway, and that women learned less about engineering as a profession during their time at community college than men. Students interviewed for this study also reported that learning more about the range of opportunities available within engineering helped them narrow their choice of majors and plan for their future. Therefore, providing more information about engineering career paths and opportunities to connect with professional engineers could be very valuable for women in community college. 


\section{Strengthen interpersonal relationships, networking, mentorship}

In this study, students mentioned that involvement in extracurricular activities could benefit them academically, socially, and professionally. Students who had received mentorship indicated that this was an important source of guidance and encouragement. Some students also said that they were interested in joining professional societies, but very few students in our study were members of such organizations.

Because research shows that extracurricular involvement, particularly academic and professional activities, is tied to students' persistence in STEM, making it easier for students to participate in these activities would be beneficial. Some faculty interviewed for this study shared ways in which they try to help students develop the types of professional networks that can lead to internships and mentors. A couple of them provided examples of activities and events that they have developed to bring in engineers and IT professionals to interact with students. Some faculty expressed concerns about the way in which certain networking activities are currently managed. One common challenge expressed was that a lot of this work falls to individual faculty members rather than a department or college, placing such activities at-risk of ceasing if the individual stops.

\section{Focus on boosting confidence}

Our survey findings were consistent with other studies showing that women tend to be less confident in math and science, despite having equal abilities in these areas. Decreased confidence among women (or over-inflated confidence among men) contributes to differential rates of persistence. Research suggests that interventions intended to counteract stereotypes and increase confidence of women in math can have a measurable impact on both performance and persistence in STEM. These interventions can include strategies such as explicitly stating in a testing context that women and men are known to perform equally well [34], providing opportunities for undergraduate research [35], and connecting women with same-gender expert in STEM [36].

\section{Conclusion}

This research was conducted to gain a better understanding of the challenges and barriers facing women on the transfer pathway in their pursuit of an engineering or computer science baccalaureate degree, and to identify factors that contribute to success from the perspective of women preparing to transfer. Our aim was to determine areas where additional supports from institutions and professional societies can help reduce women's high attrition rates observed in our first study of transfer success in Texas. What we discovered is that many factors affect both men's and women's progress in these programs, and that the gender differences are not as stark as we had expected, but there are some ways in which additional supports could help increase the success of students on the transfer pathway. 


\section{Appendix A: APPLES2 and LAESE Survey Items}

APPLES2 Multi-Item Variables

- Motivation: Financial

○ Reason: Engineers make more money than most other professionals

$\circ$ Reason: Engineers are well paid

○ Reason: An engineering degree will guarantee me a job when I graduate

- Motivation: Parental Influence

○ Reason: My parents would disapprove if I chose a major other than engineering

- Reason: My parents want me to be an engineer

- Motivation: Social Good

○ Reason: Technology plays an important role in solving society's problems

- Reason: Engineers have contributed greatly to fixing problems in the world

- Reason: Engineering skills can be used for the good of society

- Motivation: Mentor Influence

- Reason: A faculty member, academic advisor, teaching assistant or other university affiliated person has encouraged and/or inspired me to study engineering

- Reason: A non-university affiliated mentor has encouraged and/or inspired me to study engineering

○ Reason: A mentor has introduced me to people and opportunities in engineering

- Agree/disagree: A mentor has supported my decision to major in engineering

- Motivation: Intrinsic Psychological

○ Reason: I feel good when I am doing engineering

$\circ$ Reason: I think engineering is fun

○ Reason: I think engineering is interesting

- Motivation: Intrinsic Behavioral

○ Reason: I like to build stuff

○ Reason: I like to figure out how things work

- Confidence in Math and Science Skills

○ Confidence: Math ability

○ Confidence: Science ability

- Confidence: Ability to apply math and science principles in solving real world problems

- Confidence in Professional and Interpersonal Skills

○ Confidence: Self confidence (social)

- Confidence: Leadership ability

- Confidence: Public speaking ability

- Confidence: Communication skills

○ Confidence: Business ability (not included in this study)

- Confidence: Ability to perform in teams

- Confidence in Solving Open-Ended Problems

- Agree/disagree: Creative thinking is one of my strengths

- Agree/disagree: I am skilled at solving problems with multiple solutions

○ Confidence: Critical thinking skills 
LAESE Subscales

- Engineering career success expectations

- Someone like me can succeed in an engineering career

- A degree in engineering will allow me to obtain a well paying job

- I expect to be treated fairly on the job. That is, I expect to be given the same opportunities for pay raises and promotions as my fellow workers if I enter engineering

- A degree in engineering will give me the kind of lifestyle I want

- I expect to feel "part of the group" on my job if I enter engineering

- A degree in engineering will allow me to get a job where I can use my talents and creativity

- A degree in engineering will allow me to obtain a job that I like

- Engineering self-efficacy I

- I can succeed in an engineering curriculum

- I can succeed in an engineering curriculum while not having to give up participation in my outside interests (e.g. extra curricular activities, family, sports)

- I will succeed (earn an A or B) in my physics courses

- I will succeed (earn an A or B) in my math courses

- I will succeed (earn an A or B) in my engineering courses

- Feeling of inclusion

- I can relate to the people around me in my class

- I have a lot in common with the other students in my classes

- The other students in my classes share my personal interests

- I can relate to the people around me in my extra-curricular activities

- Coping self-efficacy

- I can cope with not doing well on a test

- I can make friends with people from different backgrounds and/or values

- I can cope with friends' disapproval of chosen major

- I can cope with being the only person of my race/ethnicity in my class

- I can approach a faculty or staff member to get assistance

- I can adjust to a new campus environment

- Math outcome expectations

○ Doing well at math will enhance my career/job opportunities

- Doing well at math will increase my sense of self worth

- Taking math courses will help me to keep my career options open 


\section{Appendix B: Respondent Demographics}

Survey Respondents:

\begin{tabular}{|c|c|c|}
\hline & Frequency & Percent \\
\hline \multicolumn{3}{|l|}{ English as first language: } \\
\hline Yes & 192 & 58.5 \\
\hline No & 136 & 41.5 \\
\hline Total & 328 & 100.0 \\
\hline \multicolumn{3}{|l|}{ First-generation student: } \\
\hline Yes & 128 & 39.3 \\
\hline No & 195 & 59.8 \\
\hline I prefer not to answer & 3 & .9 \\
\hline Total & 326 & 100.0 \\
\hline \multicolumn{3}{|l|}{ Student status: } \\
\hline Full-time student & 225 & 68.6 \\
\hline Part-time student & 96 & 29.3 \\
\hline I prefer not to answer & 7 & 2.1 \\
\hline Total & 328 & 100.0 \\
\hline \multicolumn{3}{|l|}{ Employment status: } \\
\hline Working full-time & 77 & 27.5 \\
\hline Working part-time & 102 & 36.4 \\
\hline Not employed & 101 & 36.1 \\
\hline Total & 328 & 100.0 \\
\hline \multicolumn{3}{|l|}{ Family income: } \\
\hline High income & 8 & 2.5 \\
\hline Upper-middle income & 49 & 15.0 \\
\hline Middle income & 108 & 33.1 \\
\hline Lower-middle income & 84 & 25.8 \\
\hline Low income & 62 & 19.0 \\
\hline I prefer not to answer & 15 & 4.6 \\
\hline Total & 326 & 100.0 \\
\hline \multicolumn{3}{|c|}{ Married/live with partner: } \\
\hline Yes & 95 & 29.1 \\
\hline No & 223 & 68.4 \\
\hline I prefer not to answer & 8 & 2.5 \\
\hline Total & 326 & 100.0 \\
\hline \multicolumn{3}{|l|}{ Primary caregiver: } \\
\hline Yes & 43 & 13.2 \\
\hline No & 274 & 84.0 \\
\hline I prefer not to answer & 9 & 2.8 \\
\hline Total & 326 & 100.0 \\
\hline \multicolumn{3}{|l|}{ International student: } \\
\hline Yes & 60 & 18.3 \\
\hline No & 261 & 79.8 \\
\hline I prefer not to answer & 6 & 1.8 \\
\hline Total & 327 & 100.0 \\
\hline Average Age: & 25 years old & \\
\hline
\end{tabular}


Interview Respondents

\begin{tabular}{|l|l|l|l|}
\hline & Age & Race/Ethnicity & Discipline \\
\hline StudentB1 & 22 & Native American, Latina, and White & Civil or Environmental Engineering \\
\hline StudentA1 & 35 & Black & Computer Engineering \\
\hline StudentA2 & 30 & White & $\begin{array}{l}\text { Environmental or Bio-Agricultural } \\
\text { Engineering }\end{array}$ \\
\hline StudentA3 & 25 & Latina and White & Computer or Software Engineering \\
\hline StudentA4 & 51 & Native American, Latina, and White & Electrical Engineering \\
\hline StudentC1 & 19 & Black & Electrical Engineering \\
\hline StudentC2 & 20 & Black & Civil or Mechanical Engineering \\
\hline StudentC3 & 20 & Asian & Chemical or Materials Engineering \\
\hline
\end{tabular}




\section{Appendix C: Mean Construct Results by Gender and Race/Ethnicity}

\begin{tabular}{|c|c|c|c|c|c|c|}
\hline \multirow[b]{2}{*}{ Construct } & \multicolumn{3}{|c|}{ Mean (scale of $0-100$ ) } & \multicolumn{3}{|c|}{ Mean (scale of $0-100$ ) } \\
\hline & $\begin{array}{l}\text { Wome } \\
\mathrm{n}\end{array}$ & Men & Sig. & URM & $\begin{array}{l}\text { Non- } \\
\text { URM }\end{array}$ & Sig. \\
\hline Feeling of Inclusion & 67.65 & 69.99 & 0.367 & 68.97 & 69.72 & 0.063 \\
\hline Engineering Self-Efficacy & 81.56 & 82.74 & 0.792 & 82.21 & 82.73 & 0.947 \\
\hline $\begin{array}{l}\text { Engineering Career Success } \\
\text { Expectations }\end{array}$ & 82.52 & 83.87 & 0.985 & 84.38 & 82.87 & 0.172 \\
\hline Math Outcome Expectations & 83.33 & 82.58 & 0.470 & 83.66 & 82.22 & 0.608 \\
\hline Coping Self-Efficacy & 83.26 & 82.62 & 0.667 & 83.10 & 83.03 & 0.522 \\
\hline $\begin{array}{l}\text { Confidence in Math and Science } \\
\text { Skills }\end{array}$ & 73.25 & 76.29 & 0.147 & 75.56 & 75.09 & 0.421 \\
\hline $\begin{array}{l}\text { Confidence in Professional and } \\
\text { Interpersonal Skills }\end{array}$ & 71.06 & 72.70 & 0.583 & 73.49 & 70.82 & 0.137 \\
\hline $\begin{array}{l}\text { Confidence in Solving Open- } \\
\text { Ended Problems }\end{array}$ & 82.35 & 82.43 & 0.189 & 82.84 & 81.83 & 0.509 \\
\hline
\end{tabular}

\begin{tabular}{|c|c|c|c|c|c|c|}
\hline \multirow[b]{2}{*}{ Construct } & \multicolumn{6}{|c|}{ Mean (scale of 0-100) } \\
\hline & Women & Men & Sig. & URM & $\begin{array}{l}\text { Non- } \\
\text { URM }\end{array}$ & Sig. \\
\hline Financial Motivation & 74.61 & 73.70 & 0.428 & 72.39 & 75.62 & 0.204 \\
\hline Social Good Motivation & 87.84 & 85.78 & 0.045 & 88.62 & 84.54 & 0.787 \\
\hline Mentor Influence Motivation & 50.68 & 49.44 & 0.368 & 51.15 & 49.25 & 0.252 \\
\hline Intrinsic Psychological Motivation & 87.55 & 87.69 & 0.420 & 88.72 & 86.86 & 0.632 \\
\hline Intrinsic Behavioral Motivation & 88.25 & 89.90 & 0.397 & 89.77 & 88.84 & 0.684 \\
\hline Parental Influence Motivation & 32.79 & 34.55 & 0.048 & 34.49 & 33.46 & 0.177 \\
\hline
\end{tabular}




\section{References}

[1] "Digest of education statistics 2018," U.S. Department of Education, Institute of Education Sciences, National Center for Education Statistics, 2018.

[2] A. P. Carnevale, N. Smith, M. Melton, and E. Price, "Learning While Earning: The New Normal.," Georget. Univ. Cent. Educ. Workforce, 2015.

[3] "Science and Engineering Indicators 2020: The State of U.S. Science and Engineering," National Science Board, National Science Foundation, Alexandria, VA, 2020.

[4] T. A. Council and N. R. Council, Community colleges in the evolving STEM education landscape: Summary of a summit. National Academies Press, 2012.

[5] N. R. Council, Enhancing the community college pathway to engineering careers. National Academies Press, 2006.

[6] L. Horn and P. Skomsvold, "Community college student outcomes: 1994-2009," Wash. DC Natl. Cent. Educ. Stat., 2011.

[7] "The Role of Community Colleges in Postsecondary Success: Community Colleges Outcomes Report,” National Student Clearinghouse Research Center, Herndon, VA, 2017.

[8] X. Chen and M. Soldner, "STEM attrition: College students' paths into and out of STEM fields (NCES 2014-001). Washington, DC: National Center for Education Statistics, Institute of Education Sciences, US Department of Education,” Inst. Educ. Sci. US Dep. Educ., 2013.

[9] R. J. Burke and M. C. Mattis, Women and minorities in science, technology, engineering, and mathematics: Upping the numbers. Edward Elgar Publishing, 2007.

[10] P. D. Jenkins and J. Fink, "Tracking transfer: New measures of institutional and state effectiveness in helping community college students attain bachelor's degrees," 2016.

[11] R. Rincon, "Diversifying STEM: Student success and community college transfer in engineering and computer science in Texas," Societiy of Women Engineers, 2017.

[12] R. M. Marra and B. Bogue, "Women engineering students' self efficacy--a longitudinal multiinstitution study," Women Eng. ProActive Netw., 2006.

[13] K. M. Donaldson, H. L. Chen, G. Toye, M. Clark, and S. D. Sheppard, "Scaling Up: Taking the Academic Pathways of People Learning Engineering Survey (APPLES) National," in 2008 38th Annual Frontiers in Education Conference, 2008, pp. F4H-6-F4H-11.

[14] E. Litzler, "Sex segregation in undergraduate engineering majors," Ph.D., University of Washington, United States -- Washington, 2010.

[15] D. B. Knight, L. R. Lattuca, A. Yin, G. Kremer, T. York, and H. K. Ro, “AN EXPLORATION OF GENDER DIVERSITY IN ENGINEERING PROGRAMS: A CURRICULUM AND INSTRUCTION-BASED PERSPECTIVE," J. Women Minor. Sci. Eng., vol. 18, no. 1, 2012, doi: 10.1615/JWomenMinorScienEng.2012003702.

[16] S. Sheppard et al., "Exploring the Engineering Student Experience: Findings from the Academic Pathways of People Learning Engineering Survey (APPLES). TR-10-01.," Cent. Adv. Eng. Educ. NJ1, 2010.

[17] C. Adelman, Women and Men of the Engineering Path: A Model for Analyses of Undergraduate Careers. U, 1998.

[18] A. M. Penner and R. Willer, "Men's Overpersistence and the Gender Gap in Science and Mathematics:," Socius, Mar. 2019, doi: 10.1177/2378023118821836.

[19] J. Ellis, B. K. Fosdick, and C. Rasmussen, "Women 1.5 Times More Likely to Leave STEM Pipeline after Calculus Compared to Men: Lack of Mathematical Confidence a Potential Culprit,” PLOS ONE, vol. 11, no. 7, p. e0157447, Jul. 2016, doi: 10.1371/journal.pone.0157447.

[20] B. W.-L. Packard, J. L. Gagnon, O. LaBelle, K. Jeffers, and E. Lynn, "Women's experiences in the STEM community college transfer pathway," J. Women Minor. Sci. Eng., vol. 17, no. 2, 2011. 
[21] M. R. Laugerman, M. C. Shelley, S. K. Mickelson, and D. T. Rover, “The engineering admissions partnership program: A navigation strategy for community college students seeking a pathway into engineering," Int. J. Eng. Educ., vol. 29, no. 5, p. 1260, 2013.

[22] D. Jain, A. Herrera, S. Bernal, and D. Solorzano, "Critical race theory and the transfer function: Introducing a transfer receptive culture," Community Coll. J. Res. Pract., vol. 35, no. 3, pp. 252266, 2011.

[23] I. P. McPhail, Enhancing the community college pathway to engineering careers for African American students. Baltimore, Johns Hopkins Press, 2015.

[24] F. S. Laanan, S. S. Starobin, and L. E. Eggleston, "Adjustment of Community College Students at a Four-Year University: Role and Relevance of Transfer Student Capital for Student Retention," J. Coll. Stud. Retent. Res. Theory Pract., vol. 12, no. 2, pp. 175-209, 2011.

[25] L. Espinosa, "Pipelines and Pathways: Women of Color in Undergraduate STEM Majors and the College Experiences That Contribute to Persistence," Harv. Educ. Rev., vol. 81, no. 2, pp. 209-241, Jun. 2011, doi: 10.17763/haer.81.2.92315ww157656k3u.

[26] L. Tsui, "Effective strategies to increase diversity in STEM fields: A review of the research literature," J. Negro Educ., pp. 555-581, 2007.

[27] L. Blash et al., "A Long \& Leaky Pipeline: Improving transfer pathways for engineering students," Sacram. CA RP Group, 2012.

[28] Y. Xie and K. A. Shauman, Women in science: careerprocesses and outcomes. Cambridge, Mass.: Harvard Univ. Press, 2009.

[29] D. H. Kim and B. Schneider, "Social capital in action: Alignment of parental support in adolescents' transition to postsecondary education," Soc. Forces, vol. 84, no. 2, pp. 1181-1206, 2005.

[30] L. Joy and L. Marco-Bujosa, "Community College Pathways to Engineering for Women: A Challenge to Gender Stereotypes?," in Engage Everyone: Building an Inclusive Climate for Diverse Communities of Women in STEM, 2013.

[31] American Academy of Arts and Sciences, American Academy of Arts and Sciences, and Commission on the Future of Undergraduate Education, A primer on the college student journey. 2016.

[32] E. Anderson and D. Kim, "Increasing the Success of Minority Students in Science and Technology," American Council on Education, Report, Mar. 2006.

[33] Deutsch, F. (1999). Halving it all: How equally shared parenting works. Cambridge, MA: Harvard University Press.

[34] C. Good, J. Aronson, and J. A. Harder, "Problems in the pipeline: Stereotype threat and women's achievement in high-level math courses," J. Appl. Dev. Psychol., vol. 29, no. 1, pp. 17-28, Jan. 2008, doi: 10.1016/j.appdev.2007.10.004.

[35] S. H. Russell, M. P. Hancock, and J. McCullough, "Benefits of Undergraduate Research Experiences," Science, vol. 316, no. 5824, pp. 548-549, Apr. 2007, doi: 10.1126/science. 1140384.

[36] J. G. Stout, N. Dasgupta, M. Hunsinger, and M. A. McManus, "STEMing the tide: Using ingroup experts to inoculate women's self-concept in science, technology, engineering, and mathematics (STEM)," J. Pers. Soc. Psychol., vol. 100, no. 2, pp. 255-270, 2011, doi: 10.1037/a0021385. 